\title{
The Ambivalence of Structural Power: Alternative Trade Unions Challenging Transnational Automotive Companies in Russia
}

\author{
Sarah Hinz, University of Jena, Germany
}

\begin{abstract}
Russia's traditional system of employment relations was marked by an overt quiescence about past decades. From 2000 onwards, increasing numbers of transnational companies throughout Russia's booming regions gave rise to the unfolding of an alternative union movement. In Kaluga, located south-west of Moscow, plant organisations successfully struggled to receive formal recognition as negotiating unions in foreign automobile firms, not shying away from open conflict. However, processes indicate their prospects for lasting consolidation go along with certain difficulties. Successes achieved are ostensibly the result of utilising workers' strong primary bargaining power. The unions' sole local focus of conflict, as well as the absence of employers' associations, prevent negotiations for sectoral or regional agreements, possibly impairing unions' associational power. Since societal power is practically absent, a substantial shift in power balances is not yet in sight.
\end{abstract}

\section{KEYWORDS}

Russia; transnational companies; industrial relations; trade unions; automobile industry; working-class power; structural power

\section{Introduction}

The overarching globalisation as well as the multiple crises that go along with global capitalism bring multiple challenges for working-class power. As capital continues to flow away from the industrial centres, increasingly reallocating in semi-peripheral and peripheral national contexts (Silver, 2003: $41 \mathrm{ff}$.), workers of the Global North fear the erosion of established successes and revocation of their institutions (Brookes, 2015). Simultaneously, capital's exploration of new spatial fixes (Harvey, 2003: 87) puts newly emerging workforces in the Global South under pressure to form worker agency in order to hold capital's ravages at bay (Herod, 2001: 129; Brookes, 2015: 132).

The Introduction to this Special Issue details the origins and nature of various aspects of the power resources approach (PRA), which was first described by Wright (2000) and Silver (2003). This article gives an example of an application of the PRA. Globalised production, with companies operating in multiple national settings, has effects on working-class power. On the one hand, the struggle to secure locations of production, and therefore jobs and workers' reproduction, increases competition among transnational workforces (Kaplinsky, 2000: 30). On the other hand, the new capital allocation makes it difficult for workers to organise in new production contexts and to secure gains in 
exploited areas. Finally, the emerging contention threatens possibilities for transnational solidarity of workers to act together against capital in a globalised world (Bieler, 2014: 120; Brookes, 2015: 141).

The interconnectedness that comes with globalised production and markets leads to more complex value chains around the world (Gereffi, Humphrey and Sturgeon, 2005: 79). While they appear to become more fluid and difficult to grasp, they are also rather prone to disruptions. For workers this represents a gateway to exercise their most fundamental resources of structural power, characterised by both marketplace and workplace bargaining power in order to improve their fundamental working conditions (Wright, 2000: 966; Silver, 2003: 13). Structural power is able to compensate for other, weaker resources of power, that is to say associational and institutional power (Brinkmann et al., 2008: 29). This paper is based on the following thesis: If unionisation is low and labour institutions are poorly developed, workers in crucial economic branches can access resources of power that evolve from their position in the production process and within the market by forming at least temporary, yet effective agency. Strikes and other forms of protest action can disrupt the production process, causing unpredictable effects to a derived and contingent value chain (Silver, 2003: 13; Quan 2008: 94). However, while the force of structural power initially offers chances for negotiation with employers, becoming a serious and enduring adversary to capital requires catalysing temporary worker agency into steady union power. A too-strong reliance on "raw" structural power bears the risk of an increased vulnerability of existing union organisations, as it undermines established forms of conflict resolution, also provoking capital to find its own niches to enforce market power. Thus, the exercise of structural power can hold an ambivalent reality in the examination of new forms of labour agency in transnational settings.

The emergence of transnational corporations (TNCs) in Russia after 2000 illustrates the formation of national worker agency in a post-socialist context exposed to global capital. The paper gives insights into the distribution of workers' power within a frame of employment relations, fostered by a superior state, in which an alternative union movement develops. In these circumstances, structural power plays a crucial role in enforcing workers' demands. Its exercise, benefits and pitfalls are explored in relation to other resources of working-class power in Russia's post-socialist setting, which is characterised by Western automobile firms seeking new spaces of capital allocation.

This paper largely draws on empirical material gathered in 2012 and 2013 at a Volkswagen (VW) plant and its component supplier Benteler, both German firms located in the Russian oblast Kaluga, $150 \mathrm{~km}$ south-west of Moscow. The research consists of information gathered mainly through guided interviews with four workers associated with the Interregional Trade Union Workers Association (MPRA). Also interviewed more informally were three individuals who were employed as regular or agency workers at Volkswagen in Kaluga. An additional four interviews were conducted with experts associated with the German metalworkers union IG Metall, the Friedrich Ebert Foundation and the Center for Social and Labour Rights in Russia. The period being examined is limited to the struggle of the alternative union organisations for a first collective bargaining agreement at Volkswagen and Benteler, starting in 2008 and extending until the agreement was reached in 2012. Contrary to more general overviews on employment relations at Volkswagen (for example, Jürgens and Krzywdzinski,

${ }^{1}$ The term refers to a federal area in Russia which enjoys administrative autonomy but which has fewer powers than republics. 
2016: 286ff), it needs to be emphasised that this article focuses on in-depth observations of workers' struggle from perspectives linked to the alternative union movement. ${ }^{2}$

\section{Transnational Companies Conquering Russia's Car Market}

The Russian economy is characterised by a heavy reliance on natural resources. While this is likely to persist, in recent years government has identified a number of key sectors - including the automobile industry - to promote the diversification of the domestic economy. The aim is to gear towards a modernised and high-tech economy. This modernisation programme led to intensive state support and subsidies, flat taxes and the provision of tailored infrastructure in a number of selected regions throughout the country (Traub-Merz, 2015: 14). Domestic and foreign firms with facilities in Russia both benefit from these incentives. However, Western firms are required to agree to strict local-content agreements. Nevertheless, they have been able to outpace traditional Russian firms such as AvtoVaz in terms of productivity. Ford was the first foreign manufacturer, opening its site in 2005. This marked the beginning of the dominance of foreign car firms throughout Russia (Arutyunova and Orlova, 2013: 5; Traub-Merz, 2015: 16). By sales, Russia's vehicle market was one of the fastest-growing ones in the world between the mid-2000s up until $2012^{3}$ (Krkoska and Spencer, 2008: 5).

The Kaluga region has been particularly appealing for foreign car-makers; its proximity to Moscow and Western Europe and the regional government's numerous incentives account for the region's attractiveness (Falkner, 2012). As one of the largest car producers, Volkswagen located in Kaluga in 2007. Its facility in Kaluga was exclusively set up to serve Russian consumers' growing demand for foreign cars. Local-content agreements coupled with high import tariffs make parts procurement highly challenging in this economic environment. As a result, Volkswagen initially started production in Russia with semi-knocked-down (SKD) assembly, a principle where almost all parts of the final product are produced in another country before being exported to their final destination for complete assembly. Two years after production started, the firm switched to completely-knockeddown (CKD) assembly, which means production is finalised in Russia with certain parts produced domestically. The producer has since pushed for full assembly in order to fulfill local-content requirements. Given the circumstances, this is only possible through a simultaneous set-up of factories for the producer's most important - and also foreign - suppliers in Kaluga. While there are numerous Russian suppliers, most of them do not (yet) fulfil Volkswagen's specific standards for just-in-time production, indicating the firm's heavy reliance on its traditional suppliers. In this case the value chain is almost entirely fixed to the Russian national setting, with the Kaluga region at the core. Local-content obligations also demand that Volkswagen produces a fixed number of cars per annum, which must increase with each additional year of market activity.

The company's economic successes were largely due to the masses of workers the firm was constantly able to recruit. With the opening of the Volkswagen plant, as well as of several other TNCs,

\footnotetext{
2 It seems important to stress that the Russian national context represents a hostile setting for exercising basic workers' and unions' rights, which involves physical violence and threats. Therefore, the general way of referencing interviewees and informants in this article is purposeful in order to protect sources.

${ }^{3}$ However, car sales started to decline in 2013, and even collapsed in 2015 because of a generally worsening macroeconomic situation in Russia (PWC, 2016).
} 
Kaluga experienced an immense job boost. The manufacturer started production with 3000 workers, quickly rising to an estimated 6100 at the peak of its success in 2012 (Krzywdzisnki, 2011: 32; RUS Auto Connect, 2013). Numerous workers from bordering regions and from as far away as Moscow were attracted to the promising jobs in foreign firms.

\section{Stalled but Guarded - Employment Relations in Russia}

Employment relations in Russia are divided. On the one hand, there are traditional trade unions merged under the umbrella of the Federation of Independent Trade Unions of Russia (FNPR). While it is the largest of its kind in Europe with approximately 21 million members, it lost 50 million members since its founding in 1991 after the collapse of the Soviet Union (Bizyukov and Grishko, 2012: 3; RBC, 2016). The unions' main objective was and still is to establish and maintain a "social partnership" with management and the state (Ashwin and Clarke, 2002: 132ff), mostly being responsible for administering and distributing social benefits (where they persist), functioning mainly like their Soviet predecessors. The concept of class conflict is not compatible with the self-understanding of traditional unions, and is for the most part openly rejected (Olimpieva, 2012: 271).

On the other hand, there is notable frustration within parts of the workforce. These workers do not shy away from articulating their ultimate interests at the workplace concerning wages, working conditions and safety. This paved way for the foundation of a number of alternative union groups during the early years of transition. These unions focused almost entirely on conflict and agitation, often marked by militant elements. They managed to challenge the traditional "dinosaur" unions until the mid-1990s with selective but massive strike and protest action that often went beyond the factory level (Greene and Robertson, 2009: 77). This was particularly the case in important economic sectors such as mining, industry and transport. Despite their focus of action on the shop floor, one of their most considerable achievements was in the institutional sphere. In 1995, two alternative umbrella organisations - the Confederation of Labour of Russia (KTR) and the All-Russian Confederation of Labour (VKT) - were officially acknowledged. Both associations merged into the KTR in 2010 and pooled some three million members by 2012 (Bizyukov and Grishko, 2012: 3). Securing stable associational power beyond the constant utilisation of structural power proved to be especially difficult for independent union organisations, however. This was partly due to an intensification of internal organisational conflicts (Mandel, 2001: 175). Furthermore, the continuing strong support from the state that the traditional FNPR unions enjoyed can be identified as a main obstacle for alternative unions to strengthen their associational foundation. Altogether, the latter failed to establish themselves as serious counterparts within the static system of industrial relations.

The following ten years were marked by labour quiescence, an "inertia" of traditional unions and their remaining members (Vinogradova, Kozina and Cook, 2012), mute alternative unions and cyclic appearances of individual protest action. It was not until 2005 that a new alternative union movement came to the fore (Greene and Robertson, 2009: 81). Those newly emerging trade unions, independent of the traditionally grown system, have since jolted employment relations. Small union groups at company level arise out of direct conflicts between workers and employers, and quickly take the chance to address typical workers' rights and interests. As was the case in the 1990s, the "newcomer" unions concentrate in economic sectors that are characterised by significant bargaining power (Greene and Robertson, 2009: 80). What is new is that they put particular emphasis on foreign firms, whose number 
has tremendously increased after they first appeared in Russia around 2000. One of the new independent organisations is the MPRA, which is associated with the KTR (Olimpieva, 2012: 273). The union first evolved out of a militant labour conflict centring on better pay and working conditions at the newly built Ford factory near St. Petersburg in 2005. Ford was not only the first foreign auto producer to locate in Russia, but also the first comprehensively organised by the union. Within the industry and beyond, the example of the unionisation of Ford often serves as a role model for other worker organisations (Krzywdzinski, 2011: 32).

The young generation of workers, who have not experienced the turmoil of transition after the collapse of the Soviet Union and who are mostly free of their parents' inertia, have formed a new selfconsciousness in this altered economic setting. They seek higher wages and job security in transnational companies and are ready to push for collective bargaining agreements. Because traditional unions have largely missed out on the chance of gaining entry to multinationals, alternative trade unions arising from the shop floor were long uncontested (Chetvernina, 2009: 10).

\section{Alternative Unions Struggle for Admission to TNCs}

Shortly after Volkswagen set up its plant in Kaluga's industrial park, Grabtsevo, workers founded independent union groups at factory level both at Volkswagen and at Benteler, one of the producers' crucial suppliers. This action grew out of the workers' dissatisfaction with low wages and poor working conditions. According to a Volkswagen union member, workers were well aware of the transnational wage differences, despite claiming that they were - for the most part - doing the same work as workers in Germany and in other Western countries. Moreover, these workers were eager to earn more, because they perceived the wages to be too low to live a decent life in Kaluga. "This is why there are currently trade unions established; this is why the [union] movement is making progress", one worker stated, identifying wages to be the driving force for comprehensive unionisation.

With a constantly growing workforce at VW, the union gained membership as well. In order to receive legal admission, these worker organisations officially linked up with the regional trade union, MPRA. Asked why the worker organisations at VW and Benteler decided to affiliate with MPRA and not the traditional FNPR union in the automobile industry - ASM - unionists claimed that their decision was significantly influenced by their colleagues at Ford in St. Petersburg who founded an MPRA branch a few years before. Furthermore, a unionist at Volkswagen claimed, "We currently experience that a true trade union like MPRA is only able to emerge where the plant is financed by Western capital".

In the beginning, both MPRA groups in Kaluga were unimpeded by the traditional unions. The latter have long missed out on the rise of transnational firms rapidly conquering Russian consumer markets. It was not until some years later that MPRA opposed a competing union group affiliated with ASM, which organised only a fraction of members at plant level compared to MPRA. Each of the competing union groups tried to gain management's recognition - ASM offering support and collaboration, while MPRA envisioned concrete discussions surrounding working conditions. According to interviews and informants, management officials notoriously refused to communicate with any of the unions. ${ }^{4}$ Relations between the firms' management and the MPRA union were tense

4 There exist different interpretations of the smoldering labour conflict in Kaluga. For example, Jürgens and Krzywdzinski (2016: 286ff.) engage in broader perspectives, including interpretations given by management, 
and difficult from the very beginning.

For MPRA, a few years of unsuccessful attempts to achieve formal recognition as the negotiating union by Volkswagen and Benteler management went by. As the firms' economic successes constantly grew over the years, workers' discontent accelerated likewise. Wages in both firms stalled at rather low levels; even compared to other regional employers they were only slightly above average. Working conditions remained poor with long working hours, often including night, weekend and holiday shifts with few recovery phases. On the one hand, the increasing frustration of workers resulted in high levels of fluctuation - the number of those who chose to leave or were forced to do so was extremely high at VW. A turnover of one-sixth of the plant's workers per annum was the usual rate, and particularly pertains to the large number of agency workers, ranging between 12 and 20 per cent of the total workforce. Workers who go for this "exit" option tend to quickly find new jobs, including in the informal economy (Morris, 2012: 225; Gimpelson and Kapelyushnikov, 2014: 13). Management does not attach importance to binding their workers to the firm. As one informant put it, "There is no room for human relations in a capitalist firm; only money counts". On the other hand, the union groups that were eager to improve the workers' situation in the plants experienced a growing membership, which simultaneously indicates a strong shift towards "voice". Still, the long struggle for negotiations and dialogue with management proved unsuccessful. While each of the plants' managements notoriously refused to interact with MPRA as the main union for more than three years, the union eventually called their members to strike and to engage in protest action in order to articulate basic workers' interests. Henceforth, it became their primary aim to force management of both Volkswagen and Benteler into bargaining with MPRA, by threatening and eventually exercising intensive protest action.

The people here [in Russia] just don't get it. Everything depends on the people. One simple example: ... I turn to a person on the street and say 'Give me your wallet'. Maybe he gives it to me, maybe he doesn't. If I turn to that same person in a crowd of people and say 'Give me your wallet', he will give it. It is just like that with the employer. When I go to our general director and demand 'Give us all a decent wage', he will reply 'My son, go away from here'. And he will dismiss me, and there is nothing I can do about it. But in an organised group of people ... [the director will give in, eventually] (Interview, MPRA unionist at Benteler).

The plant organisations refused to call for guidance from German labour representatives, claiming they preferred to deal with conflicts on their own. This included the rejection of the installment of a German-style works council, which management tried to foster. The union leaders at both plants were dedicated to the notion that their struggle had to come from below, from the shop floor, and rather not be solved top-down by long-established union institutions, regardless of their national scheme.

Here, if we begin to start campaigning, inside we understand that the workforce, in order to get a higher wage, needs to demand more, needs to struggle more. People here will say ...: 'Work more, and then you will get more money'. But we know, one won't get more money simply by working harder. If you follow that principle, the ancient slaves in Rome would have been the richest people of the world (Interview, MPRA unionist at Benteler).

while however omitting the protest action that had taken place at Volkswagen and Benteler in 2011 and onwards, despite the fact that the events were well-documented elsewhere, particularly in various media outlets (Kagarlitsky, 2012; Lenta, 2012). 
While the "German case" would not function as a role model for the Kaluga-based workers, MPRA unionists were particularly drawn to those activists at VW in other national contexts where they were confronted with similarly hostile environments for pursuing workers' power. Therefore, the Russiabased MPRA unionists regularly participated in joint seminars organised by IG Metall. These gatherings were crucial for consensus-building within the union groups and could be viewed as acts of transnational solidarity. Learning about the militant strategies of colleagues in the Global South who were opposing capital caused the MPRA unionists to probe something similar in Kaluga. In addition, the constant reminder of the multiple and long-standing successes of the union branch active at Ford near St. Petersburg - also regular participants of those seminars - triggered and framed the action.

\section{Structural Power as a Driving Force}

The self-positioning in opposition to capital came with a willingness to demand workers' rights through severe protest action. This fundamental change was essentially the result of an organisational learning process for the union groups at plant level. This was marked by a deep disappointment with managements' consistent refusal to communicate with union representatives and workers' growing discontent with unacceptable working conditions. In the words of a Benteler unionist:

I will now explain how this is approached. There is a scale, roughly speaking. ... On the one side, there is the claim ... to raise our pay to, let's say, 40000 rubles - about 1000 Euro. On the other side, we have what we could cause the employer, in order to have him give it to us - a strike. ... The losses [are] for our company because of the strike, when our firm, to their own fault, keeps the production at Volkswagen on hold and doesn't deliver the chassis [to them] (Interview, Benteler unionist).

The close interconnections of both MPRA union organisations at the local level were crucial for the success of the new direction of the strategy taken. The geographic proximity of producer and supplier located within the industrial park aided those worker organisations ready for protest action in Kaluga. Not only did the similarities of the working conditions they faced bring them together, but so did the acknowledgement of firm dependencies within the local economic value chain as well as the hostile environment for trade unions within these firms. The main goal of both union groups was to achieve formal recognition in order to strive for legal collective bargaining agreements.

The sudden consent of new members and workers to the strategy of open conflict strongly backed the unions' change of orientation towards approaching negotiations. Benteler employed significantly fewer workers than VW at the time - 380 compared to 6000 at VW. For the union group active at the supplier, it was thus easier to unify a smaller workforce for planned protest action. In the spring of 2012, they managed to mobilise significant numbers of workers and initially went into an unlimited strike. Management was furious, confronted with a massive fall of production, amounting to around 8 million Euro for a three-day strike, but they refused to give in to the union's demand for collective bargaining negotiations at first. Simultaneously, there was an open demonstration of mutual solidarity between both firms' workforces. The stoppage, which workers initiated at Benteler, was supported by union colleagues and workers employed at Volkswagen, who demonstrated their agreement with the workers' action through temporary participation in strikes as well as offering to picket at the producer itself. In some cases, they helped disrupt deliveries of supplies carried out by strike-breakers deployed 
by Benteler management. Apparently, the work stoppage caused immediate impacts on Volkswagen. Without the required parts and no substitute supplier at hand, management had to cut back production. In fact, the producer was hit from two sides at once - first, by a forced reduction of production due to the strike activities of workers at the supplying firm, and second, by the pressure their own plant's union organisation put on management, threatening unlimited strikes as well. The open conflict uncovered Volkswagen's heavy dependency on Benteler. Even more, management's vulnerable position was exposed in the wake of workers' protest action at the supplier as well as by workers' demonstration of strong solidarity between the factories. VW executives feared that their own, increasingly self-confident, workers could call a strike at any time.

Due to the intervention of MPRA union leaders at interregional level, as well as of regional government officials acting as intermediators, the strike at Benteler ended some four days later. The outcome marked the official acceptance of MPRA as the negotiating union and management's commitment to collective bargaining negotiations. In turn, the union was obliged to call off the work stoppage immediately. The settlement had set a precedent for symbolic power, which gave little hope to VW management for success in case an open labour conflict would erupt. It seemed expedient to give in to the workers' demand for negotiations instead of provoking an unlimited work stoppage, which the emboldened workers argued they were ready to initiate. Given the circumstances, the actual surrender of VW management before the union was even able to declare an official strike indicates managements' fears of an expensive work stoppage. The risk was high that the demands and ability to follow through on the threat of strikes were supported by large parts of the workforce.

The transformation of the union's strategy towards open conflict initially proved to be successful because it was supported by a significant rise in membership, a concomitant solidarity of the workforces and the blunt disclosure of the profound dependencies within the locally fixed value chain. In essence, it took four years of smoldering industrial conflict until the workers' strike at Benteler and the support they experienced from VW colleagues gave the final twist for both firms to ultimately accede to the union demands (Hinz and Morris, 2017).

It can be argued that the union's awareness and focus on utilising workers' basic structural power was one of the most critical factors that enabled the plant organisations to succeed in the conflict. Firstly, workers employed in the automotive industry enjoy distinct marketplace bargaining power. The firms are in constant need of young and fit workers to reach their goals of serving the consumer markets. However, the firms did not put notable effort into developing the workforce, which would indicate a long-term approach to human resources management. This becomes most evident in a high turnover rate, in which many workers left voluntarily. Workers who are able to tackle the strenuous jobs in the automobile sector are increasingly in short supply. They "churn" frequently, having good chances of finding alternative jobs in the formal and informal economies, especially in a booming region such as Kaluga and within reasonable distance to Moscow (Hancké, 2011: 20; Falkner, 2012). A favourable labour market situation typically strengthens workers' marketplace bargaining power (Silver, 2003: 14). In interviews, unionists complained that the downside of a high turnover would be the difficulty of organising agency workers, particularly because they make up a significant part of the overall workforce.

Secondly, workers and unions made exemplary use of their ability to disrupt production processes by exercising their workplace bargaining power (Silver, 2003: 13). They were not only able to do so because the automobile industry is one of Russia's most significant economic sectors; Volkswagen's just-in-time-production enhances workers' power because it enables immediate delays in assembly and 
sales. This goes along with the company relying solely on facilities located in Russia for serving its domestic market. The economic and local circumstances described above prevented a switch to alternative facilities or suppliers at short notice. Finally, workers and management were aware that local-content requirements keep production in Russia, making the usual threats of relocating assembly meaningless. Particularly, the utilisation of workplace bargaining power gives workers and unions a wider range of escalation for articulating demands and exercising protest.

\section{The Fragility of Union Success and Managements' Attempt to Restore its Power}

The labour side experienced a further boost in membership during the negotiation process. At its peak, some 1200 workers were organised at Volkswagen, which equals about 23 per cent of production operatives. With almost 30 per cent, the degree of organisation at Benteler was even higher at the time.

Collective bargaining eventually resulted in joint agreements between each firm's management and union group, with a duration period of one year for the workforce at Benteler and two years for Volkswagen workers. Both agreements contained a pay raise, the implementation of a transparent wage-scale system, management's commitment to significantly reduce the use of agency labour at the plant or to stop its use altogether (which was the case at Benteler), as well as some adjustments to working-time formalities. The legitimacy to act as a dominant union also has the effect that management is prohibited from negotiating any binding agreements with competing unions at the plant, unless their membership eventually outpaces that of MPRA.

The MPRA groups at both plants were initially very successful with their strategy of articulating their demands as they forced management into collective bargaining. Up until then, management was perceived to be deeply hostile towards unions, regardless of their ultimately differing intentions. However, it soon became obvious that the union's sudden gain of associational power was fragile. Immediately after the collective bargaining agreements were signed, union membership in both plants went into considerable decline - in the case of VW from approximately 36 to 23 per cent (in production and assembly), and from around 60 to 30 per cent at Benteler. The negotiated achievements caused mixed perceptions within the workforces. Controversy about the adequacy of the claimed wages and the demand for a transparent wage-scale came to the surface. There was also some dissatisfaction with the newly implemented wage-scale because, similar to the condition before the collective action, workers could only reach the upper wage limit after a few years of plant affiliation. Low wage differences between the wage groups were also subject to criticism. The membership decline was not only the result of members'dissatisfaction, however. A part of the losses can be attributed to those workers who believed their "duty" was done and their membership was no longer required.

In the negotiation's aftermath, both union groups were well aware of the mistakes they had made as organisations. The active union members estimated that their organisations were still at a learning stage, hence, they struggle to stabilise resources within the organisations. They reflected that the open forward intermediation of combining contrasting interests of members and at the same time constantly informing the workforce about the state of negotiations with management were crucial tasks for obtaining lasting associational power. Intensive communication efforts through a variety of channels, ranging from plant newspapers to social media, have since been strategically utilised in order to keep and rebuild their members' trust and to gain that of the overall workforce, holding up the need for transparency in all union activities. Interestingly, there was no mention of wanting to further engage 
in transnational dialogue in order to stabilise organisational capacity; instead unionists persist in their lone struggle from below.

Management at both plants attempted to regain power after the conflicts were officially settled. In interviews with unionised workers at the producer, it was claimed that VW management tried to restore its superior position opposing the trade union by promoting the founding of a new, third union at the plant in order to refuse further negotiations with MPRA. This New Innovative Union's (NIP) membership allegedly consisted exclusively of white-collar workers. Their level of organisation was supposedly very low, so MPRA continued to be the strongest union at the plant. Still, the formation of the NIP served as a symbolic threat, displaying management's ability to learn and stay flexible on its own behalf. As a result, the MPRA group initiated negotiations with ASM at the plant, which led to the shared understanding that in order to be able to demonstrate a stronger voice in relations with management it was necessary to form alliances in certain conflicts despite differing self-perceptions.

During the intense conflicts of 2012, VW was the target of several acts of sabotage, ranging from the removal of cars' identification numbers, which prevents the sale of vandalised vehicles, to destroying radio systems and spraying rude words on the cars. Management suspected that the union was behind those acts of deliberate destruction and initiated a legal case. However, the union denied any involvement and was eventually acquitted by the court; the responsible saboteurs were never found.

As for Benteler, according to the interviewed unionists, management tried to have the union's strike declared illegal in court, but this move failed. For the union groups those court cases turning out in their favour were seen as confirmation of the legitimacy of their actions and successes, especially in a country known for a legal system undercut by structural injustice and comprehensive violations of universal human rights (Human Rights Watch, 2017: 440).

Underpinning associational power is difficult for various reasons, most notably because the local organisations at plant level are only loosely connected to regional offices. These are rather viewed as a junction point for a number of plant organisations with similar interests in representing workers of the industry instead of serving as an extended alliance. Alternative unions are still in an early stage of a comprehensive learning process. As organisations they are quite vulnerable, but the utilisation of strong structural power could substitute for weaker associational power. Ultimately, the first series of open protest action against Benteler and Volkswagen was an exclusively local conflict. Although organising took place along the value chain, the effects and successes did not spill over to other suppliers. Nor was the process directly fostered by MPRA officials on an interregional level, even though the new alignment of the union groups matches the self-understanding of MPRA as a conflictoriented union. That is so because the plant groups are mostly acting on their own accord and do not ask for support from the union association. This autonomy enabled them to stay exceptionally flexible within the localised conflict. It allowed them to spontaneously agitate and react to sudden changes within the process of conflict resolution, without the need to negotiate with other parties, hence avoiding bureaucratic hurdles.

\section{The Realm of Institutions, or the State as a Watchdog}

In a wider context, the union's tenuous position is further strained by its lack of institutional power. It has not succeeded in strengthening its institutional power despite collective bargaining successes and 
its formal affiliation with KTR. Some plant organisations of the MPRA, most notably those active at VW and Benteler, openly refuse to strive for institutional embedding. They persist in their strategy of focusing on the local, keen to stay flexible as organisations rather than gaining institutional power, fearing that the initial benefits of the latter could be foiled by a loss of associational power, as demonstrated by traditional unions (Olimpieva, 2012: 276). Similar to their 1990s predecessors, these newly rising unions are characterised by their refusal to transform their outstanding protest successes into lasting organisational and influential institutional power (Greene and Robertson, 2009: 92).

In order to articulate preconditions toward the government, the precondition in the plant must be improved first. If we don't accomplish improvements in the plant, it is not worth mentioning to address the government and propose any preconditions. A plant is a little state as such (Interview, MPRA union activist).

The low level of institutional protection bears risks that undermine chances to fully evolve under the given hostile circumstances. Collective bargaining agreements, where they have been reached, are exclusively limited to plant level. Comprehensive negotiations with at least a sectoral-regional coverage do not exist, which limits the unions' influence to a local level. The most notable reason for this situation is the continued focus on improving basic working conditions within the factories of the local yet diverse plant organisations in the industry. Binding agreements beyond the plant seem "far away" for those whose fundamental struggle revolves around the basic recognition of a workers' union by management. This goes along with another profound reason: The institutional avenues of activity are limited for the MPRA because employers have no intention to organise themselves - neither employers of 'TNCs nor those within the automotive industry in general belong to employers' associations. To reach sectoral collective agreements under these circumstances is almost impossible. The absence of employer associations is more revealing about trade union power than employers' power, however. The latter see no need to associate, because they do not perceive unions as a serious adversary (Artus, 2013: 110). This is crucial because the transformation of associational power to forms of institutional embedding could legitimise the unions' successful achievements at plant level and could pave the way to negotiations for collective agreements at branch, regional or even national level. For the unions' associational power, this would mean not only being backed by the exercise of primary power but moreover experiencing support of institutional agreements, the result of hard struggle in an arena possibly more hostile than the actual foreign factory.

An omnipresent state is also responsible for the restrained and limited institutional power, because the government has no interest in changing employment relations as this would likely give alternative, conflict-oriented unions opportunity to gain power on a societal level (Greene and Robertson, 2009: 91). The unions could possibly reveal ambitions to ultimately interfere in policy-making and even gain the capability to provoke wider forms of social unrest, as was the case during transition in the 1990s. Since then, the government has been eager to restore the traditional unions as seemingly influential actors in employment relations, despite their eroding associational power (Ashwin and Clarke, 2002: 265). An overall reform of the Russian labour code was a crucial step already taken in 2001 in order to fundamentally restrict smaller unions' rights and capabilities to agitate, while also consolidating the designated role of traditional unions as mere gatekeepers (Olimpieva, 2012: 281).

In the case of the labour conflicts taking place in Kaluga, the all-observing state is supposed to have demonstrated its power in a direct and unapologetic way. Shortly after the conflicts were settled 
in 2012, some union members were reportedly questioned by the Kaluga branch of the infamous Centre "E", a department of the regime assigned to fight terror and extremism (Tumanov, 2012; Karavayev and Lomakin, 2015). Eventually the people in question were released, but they did not know what the initial purpose or outcome of the investigation was. By questioning key figures, government strives to find out whether alternative unions are affiliated with or being financed by institutions of foreign countries. Informants claim that these actions taken by the government are meant to threaten unionists in order to force labour quiescence. The incidents and purposeful attempts to intimidate active unionists suggest an ongoing hostility of the state towards (alternative) trade union action.

A substantial institutional embedding of alternative unions - if the government would tolerate such a development in the first place, which is highly unlikely - could even foster societal power as it would demonstrate strength and endurance of alternative unions challenging not only foreign firms but the entire system of employment relations. But so far, as a rather small trade union association organising mostly in transnational and automotive companies in certain regions, acting in an obscure and fragmented overall system of employment relations, MPRA's scope to reach out to large parts of the working class or to society in general is very limited. However, at the local level, alternative union groups like the ones at VW and Benteler received a great deal of support by people during open conflicts, according to workers employed at the Kaluga plants. Indeed, many people would find it intolerable to accept the exploitation of workers by the suddenly omnipresent global firms, whose management style is known to be particularly draconian. Strict rules and a heavy work regime oppose the rather laissez-faire style of many domestic firms. One can assume that the frequent and sometimes intense protest action in global firms does not go unnoticed in larger parts of Russian society and likely contributes to a certain public image of (alternative) trade unions as well as TNCs. Yet research on the possible effects of the eruption of an alternative union movement and the consequences for the consciousness of the working class still needs to be conducted.

\section{Conclusions}

Bottom-up processes of unionisation in TNCs can help break the path dependency of post-communist employment relations, despite employer and state hostility (Meardi, 2008: 188). The exceptionally strong structural power that workers successfully utilised in Kaluga is not just a given because of the automotive industry's significance for economies in general, but is accounted for by TNCs' sole focus on domestic markets combined with rigid local-content requirements and other suitable job options for workers. Processes of globalisation may give rise to communities of struggle that compensate for nation-specific weaknesses of workers' power. The case presented here indicates that fragile associational and institutional power could be partially substituted by demonstrating structural bargaining power. Hence, the union's most critical factor for success is simultaneously its most critical factor for failure because the strong reliance on this bare form of power increases the organisation's overall vulnerability and its reluctance to push for institutional embedding. This becomes most evident in the current melee of Western sanctions and the significant breakdown of the automobile industry in 2015, when jobs were cut and production reversed. Examining the union's capabilities to manoeuvre the difficult tasks arising from the collapse of sales, the possible withdrawal of state incentives, unpredictable managements as well as an uncertain political future requires further comprehensive examination. As of March 2018, the alarming yet mostly unpublicised events taking place - particularly 
the questionable decision by a city court in St. Petersburg to annihilate the trade union MPRA (IndustriALL, 2018) - not only call for transnational solidarity among unions but urge for a stronger involvement of the scientific community to engage in these pressing problems in Russia.

\section{REFERENCES}

Arrighi, G. (1994) The Long Twentieth Century: Money, Power, and the Origins of our Times. London: Verso.

Artus, I. (2013) Ausländische Systeme der industriellen Beziehungen. In Lexikon der Arbeits- und Industriesoziologie, edited by H. Hirsch-Kreinsen and H. Minssen. Berlin: Edition Sigma.

Arutyunova, D. and V. Orlova (2013) The Russian Car Industry in the Conditions of Globalisation: Factors, Features, Development Strategies. Taganrog: Southern Federal University.

Ashwin, S. and S. Clarke (2002) Russian Trade Unions and Industrial Relations in Transition. Basingstoke and New York: Palgrave Macmillan.

Bieler, A. (2014) Transnational Labour Solidarity in (the) Crisis. Global Labour Journal, 5(2): 114-33.

Bizyukov, P. and O. Grishko (2012) Gewerkschaften in Russland. Moscow: Friedrich Ebert Stiftung.

Brinkmann, U., H.-L. Choi, R. Detje, K. Dörre, H. Holst, H. Karakayali and C. Schmalstieg (2008) Strategic Unionism: Aus der Krise zur Erneuerung? Umrisse eines Forschungsprogramms. Wiesbaden: VS Verlag für Sozialwissenschaften.

Brookes, M. (2015) Power, Labour, and Globalization: How Context-appropriate Strategies help Transnational Labour Alliances Succeed. Labour and Transnational Action in Times of Crisis, edited by A. Bieler, R. Erne, D. Golden, I. Helle, K. Kjeldstadli, T. Matos and S. Stan. Lanham: Rowman \& Littlefield.

Chetvernina, T. (2009) Trade Unions in Transitional Russia: Peculiarities, Current Status and New Challenges. Russian Research Center Working Paper Series No. 16, Hitotsubashi University, Tokyo.

Falkner, J. (2012) Kaluga. Die Probleme einer Boomregion. In Russland 2011. Zwischen Aufbruch und Wirklichkeit. Jahresbericht der Deutsch-Russischen Außenhandelskammer, Ost-West-Contact 01/2012, edited by German Chamber of Commerce (GCC). Hamburg: GCC.

Gereffi, G., J. Humphrey and T. Sturgeon (2005) The Governance of Global Value Chains. Review of International Political Economy, 12(1): 78-104.

Gimpelson, V. and Kapelyushnikov, R. (2014) Between Light and Shadow: Informality in the Russian Labour Market. IZA Discussion Paper Series No. 8279. Bonn: Institute for the Study of Labor.

Greene, S.A. and G.B. Robertson (2009) Politics, Justice and the New Russian Strike. Journal of Communist and Post-Communist Studies, 43(1): 33-54.

Hancké, B. (2011) Endogenous Coordination. Multinational Companies and the Production of Collective Goods in Central and Eastern Europe. LSE Europe in Question Series (LEQS) 41/2011. London: London School of Economics and Political Science.

Harvey, D. (2003) The New Imperialism. Oxford: Oxford University Press.

Herod, A. (2001) Labour Geographies. Workers and Landscapes of Capitalism, New York: Guilford Press.

Hinz, S. and J. Morris (2017) Trade Unions in Transnational Automotive Companies in Russia and Slovakia. Prospects for Working-class Power. European Journal of Industrial Relations, 23(1): 97-112.

Human Rights Watch (2017) World Report 2018. Events of 2017. New York: Human Rights Watch.

IndustriALL Global Union (2018) International and Russian Trade Union Movement Opposes the Dissolution of ITUWA. http://www.industriall-union.org/international-and-russian-trade-union-movement-opposes- 
the-dissolution-of-ituwa (accessed 26 March 2018).

Jürgens, U. and M. Krzywdzinski (2016) New Worlds of Work: Varieties of Work in car Factories in the BRIC Countries. Oxford: Oxford University Press.

Kagarlitsky, B. (2012) Labor Protests Pose New Kremlin Headache. Moscow Times, 5 April 2012. https://themoscowtimes.com/articles/labor-protests-pose-new-kremlin-heacache-13827 (accessed 28 May 2018).

Kaplinsky, R. (2000) Spreading the Gains from Globalisation: What can be Learned from V alue Chain Analysis? IDS Working Paper 110. Brighton: IDS.

Karavayev, A. and D. Lomakin (2015) Автопром проверили на экстремизм. Сотрудники Центра «Э» задержали активистов независимого профсоюза в Калуге [The automobile industry was checked for extremism. Employees from Centre "E" detained activists of an independent trade union.]. Gaseta, 23 May 2015. https://www.gazeta.ru/auto/2015/03/23 a 6611145.shtml (accessed 30 September 2016).

Krkoska, L. and A. Spencer (2008) Automotive Industry in Russia: Impact of Foreign Investments in Car Assembly Plants on Suppliers' Entry. London: European Bank for Reconstruction and Development.

Krzywdzinski, M. (2011) Neuordnung der Macht: Die industriellen Beziehungen in Russlands Autoindustrie wandeln sich. WZB Mitteilungen, 133: 29-33.

Lenta (2012) Workers of Kaluga Factory Agree to Stop the Strike. Lenta.R $u, 1$ April 2012. https://lenta.ru/news/2012/03/31/nostrike (accessed 28 May 2018).

Mandel, D. (2001) Why is there no Revolt? The Russian Working Class and Labour Movement. Socialist Register 2001, 37: 171-95.

Meardi, G. (2008) Multinationals in the New EU Member States and the Revitalisation of Trade Unions. Journal of Contemporary Central and Eastern Europe, 15(2): 177-93.

Morris, J. (2012) Unruly Entrepreneurs: Russian Worker Responses to Insecure Formal Employment. Global Labour Journal, 3(2): 217-236.

Olimpieva, I. (2012) Labor Unions in Contemporary Russia. An Assessment of Contrasting Forms of Organisation and Representation. The Journal of Labor and Society: The Changing Shape of Unions and Working Class Organisations. Lessons from North America and Europe, 15(2): 267-83.

PricewaterhouseCoopers (PWC) (2016) Russian Passenger Car Market and Commercial Vebicle Market: 2015 Results and Outlook. Moscow: PricewaterhouseCoopers Russia.

Quan, K. (2008) Use of Global Value Chains by Labor Organizers. Competition \& Change, 12(1): 89-104.

RosBusinessConsulting (RBC) (2016) Расследование РБК: на что живут российские профсоюзы [Investigation by RBC: What Trade Unions Stand For]/ РБK, 29 April 2016. http://www.rbc.ru/investigation/society/29/04/2016/572214189a79477116812c57 (accessed 16 September 2016).

RUS Auto Connect (2013): List of Region-based Automotive Plants. http://www.rusautoconnect.com/en/ central/13-kaluga.html?page $=8$ (accessed 23 February 2015).

Silver, B.J. (2003) Forces of Labor: Workers' Movements and Globalization since 1870. Cambridge: Cambridge University Press.

Traub-Merz, R. (2015) Öl oder Autos. Chancen einer Re-Industrialisierung Russlands. Moscow: Friedrich Ebert Stiftung.

Tumanov, G. (2012) The Dark Doings of Russia's Centre E. Open Democracy, 28 August 2012. https://www.opendemocracy.net/od-russia/grigory-tumanov/dark-doings-of-russia $\%$ e $2 \% 80 \% 99 \mathrm{~s}-$ centre-e (accessed 16 September 2016). 
Vinogradova, E., I. Kozina and L. Cook (2012) Russian Labor: Quiescence and Conflict. Communist and PostCommunist Studies, 45(3-4): 219-31.

Wallerstein, I. (2007) World-System Analysis: An Introduction. Durham, NC: Duke University Press.

Wright, E.O. (2000) Working-class Power, Capitalist-class Interests, and Class Compromise. American Journal of Sociology, 105(4): 957-1002.

\section{BIOGRAPHICAL NOTE}

SARAH HINZ is a research assistant and $\mathrm{PhD}$ candidate at the Institute for Sociology at the University of Jena, Germany. Her research centres on work and precarity as well as employment relations in Germany and Russia, with a particular focus on strategic choice. [Email: sarah.hinz@uni-jena.de] 